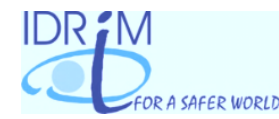

Journal of Integrated Disaster Risk Management

Original paper

\title{
Communication-design for Disaster Risks through Shopping at a Large-scale Shopping Center: Transition from Disaster Prevention to Disaster Mitigation
}

\author{
Hironori Yamaguchi ${ }^{*}$, Naoko Horie ${ }^{2}$
}

Received: 30/11/2017 / Accepted: 27/09/2018 / Published online: 19/11/2018

\begin{abstract}
This research focuses on the planning, implementation and evaluation of a disaster drill in cooperation with diverse entities in the community for building resilience. The research field was developed in Kusatsu City, Shiga Prefecture as a participatory action research through collaborative practice with a community development organization. We organized a workshop where the participants were gathered at a large-scale shopping center and instructed to buy commodities they considered necessary for surviving 3 days after a mega earthquake. And then they were asked to share their comments on this activity. After the workshop the participants actually used these commodities for 3 days at home and exchanged their stories at the follow-up seminar held six days after the workshop. In this research, we attempted a textual analysis of 2,585 posts in SNS and a phenomenological description about the whole process of disaster drills from the viewpoint of social psychology.
\end{abstract}

Key words Resilience; Drill; Scenarios; Co-occurrence network; Activity theory.

\section{INTRODUCTION}

\subsection{Background}

After the Great East Japan Earthquake, the Cabinet Office considers Japan to be in the stage of "disaster prevention 4.0". As shown in Table 1, the stages in the disaster prevention mode in Japan have been upgraded as the scale and magnitude of the disasters increased. Namely, it was set to be 1.0 after Ise Bay Typhoon (1959), 2.0 after Hanshin-Awaji Earthquake (1995), and 3.0 after East Japan Great Earthquake (2011). Under the current stage 4.0, Japanese citizens are alerted for the disasters of unprecedented scales caused by climate change. From December 17, 2015, the panel

\footnotetext{
${ }^{1}$ Ritsumeikan University, Japan, e-mail: gucci@fc.ritsumei.ac.jp

${ }^{2}$ Kusatsu Mirai Project, Japan.

${ }^{*}$ Corresponding author.
} 
of experts was held with the aim of "developing a new direction of measures against disaster prevention so that not only the governmental administration but also every Japanse citizen in local communities could be better-prepared for the risks of disasters. In the proposal of June 2016, following suggestions are made: "stocking up food and daily necessities for 'the minimum 3 days, preferably 1 week if possible' as preparation for residents and regions; sharing the information in advance with family members about the way of evacuation; and collecting the latest information and responding flexibly to the disaster" (The Cabinet of Japan 2016, p.25).

Table 1. The mode of "Disaster Prevention 4.0" in Japan (The Cabinet of Japan, 2016) (Translated by the 1 st author)

\begin{tabular}{|c|c|c|c|c|}
\hline & $\begin{array}{l}\text { Epoch } \\
\text { period }\end{array}$ & Damage & Causes & Measures \\
\hline $\begin{array}{l}\text { Disaster } \\
\text { prevention } \\
\quad 1.0\end{array}$ & $\begin{array}{l}\text { Ise Bay } \\
\text { Typhoon } \\
(1959)\end{array}$ & $\begin{array}{l}\text { Extensive human } \\
\text { and physical } \\
\text { damage caused } \\
\text { by a large typhoon }\end{array}$ & $\begin{array}{l}\text { Absence of unified } \\
\text { system and regime } \\
\text { against disaster } \\
\text { prevention }\end{array}$ & $\begin{array}{l}\text { Establishment of Disaster } \\
\text { Countermeasures Act } \\
\text { (Establishment of central disaster } \\
\text { prevention council, Creation the } \\
\text { implementation of the Basic Disaster } \\
\text { Management Plan which is a } \\
\text { comprehensive and long-term plan on } \\
\text { disaster prevention }\end{array}$ \\
\hline \multirow[b]{2}{*}{$\begin{array}{l}\text { Disaster } \\
\text { prevention } \\
\quad 2.0\end{array}$} & \multirow{2}{*}{$\begin{array}{l}\text { Hanshin- } \\
\text { Awaji } \\
\text { Earthquake } \\
\quad(1995)\end{array}$} & \multirow{2}{*}{$\begin{array}{l}\text { Vast damage due } \\
\text { to urban disaster } \\
\text { such as collapse } \\
\text { of houses and } \\
\text { shredding of } \\
\text { lifeline, } \\
\text { Paralysis of traffic } \\
\text { system and } \\
\text { Occurrence of } \\
\text { many victims }\end{array}$} & $\begin{array}{l}\text { Inadequacies of the } \\
\text { government's crisis } \\
\text { management system, } \\
\text { issues in initial response }\end{array}$ & $\begin{array}{l}\text { Improvement of initial government } \\
\text { structure such as establishment of an } \\
\text { emergency convocational team in Prime } \\
\text { Minister's Official Residence }\end{array}$ \\
\hline & & & $\begin{array}{l}\text { Widespread damages } \\
\text { caused by collapse of } \\
\text { buildings with insufficient } \\
\text { earthquake resistance, } \\
\text { many vulnerable victims } \\
\text { faced difficulties for } \\
\text { revitalization }\end{array}$ & $\begin{array}{l}\text { Establishment of Act on Promotion of the } \\
\text { Earthquake-proof Retrofit of Buildings } \\
\text { (1995), Establishment of Act on Support } \\
\text { for Livelihood Recovery of Disaster } \\
\text { Victims (1998) }\end{array}$ \\
\hline \multirow[t]{2}{*}{$\begin{array}{l}\text { Disaster } \\
\text { prevention } \\
\quad 3.0\end{array}$} & \multirow[t]{2}{*}{$\begin{array}{l}\text { East Japan } \\
\text { Great } \\
\text { Earthquake } \\
\quad(2011)\end{array}$} & \multirow{2}{*}{$\begin{array}{l}\text { The greatest } \\
\text { earthquake ever } \\
\text { recorded in Japan, } \\
\text { Extreme severity } \\
\text { and idespread } \\
\text { Disaster by major } \\
\text { tsunami }\end{array}$} & $\begin{array}{l}\text { Inadequate preparation } \\
\text { for disaster assuming } \\
\text { maximum class }\end{array}$ & $\begin{array}{l}\text { Revision of the damage estimation and } \\
\text { countermeasures for the large-scale } \\
\text { earthquake, Positioning the concept of } \\
\text { "disaster reduction" as a basic principle, } \\
\text { countermeasures against the largest } \\
\text { assumed floods etc. (revised Flood } \\
\text { Control Act), Improvement of framework } \\
\text { for reconstruction at large-scale disasters }\end{array}$ \\
\hline & & & $\begin{array}{l}\text { Inadequate assumption } \\
\text { for combined disaster of } \\
\text { natural disaster and } \\
\text { nuclear disaster }\end{array}$ & $\begin{array}{l}\text { Revision of nuclear energy policy by the } \\
\text { establishment of Nuclear Regulation } \\
\text { Authority (2012) }\end{array}$ \\
\hline $\begin{array}{l}\text { Disaster } \\
\text { prevention } \\
4.0\end{array}$ & \multicolumn{2}{|c|}{$\begin{array}{l}\text { Disaster Intensification caused by } \\
\text { climate change accompanying } \\
\text { global warming }\end{array}$} & \multicolumn{2}{|c|}{$\begin{array}{l}\text { Disaster prevention phase (4.0) towards a society where each citizen } \\
\text { views disaster reduction as "my own affair" to facilitate participation to } \\
\text { increase resilience by diverse entities }\end{array}$} \\
\hline
\end{tabular}

In the era of disaster prevention 4.0, the Japanese government is struggling to find ways to enhance "national resilience". This policy is pursued under the "Basic Act for National Resilience Contributing to Preventing and Mitigating Disasters for Developing Resilience in the Lives of the Citizenry" (Act No. 95 of 11 December 2015). In the pamphlet that promotes this policy, the Cabinet Office of Japan uses the metaphor of a prominent major league baseball player as a model to enlighten the readers as to the importance of daily maintenance: "Ichiro has been strengthening his physical and mental abilities through the accumulation of his daily effort for many years and succeeded at the forefront of Japan and the US professional baseball." (The Cabinet Secretariat of Japan 2016, p.3) The pamphlet also explains the importance of properly combining the hardware 
construction (such as improvement of embankment and evacuation facilities) and software approach (such as utilization of hazard maps and implementation of various disaster evacuation drills) to reduce disaster risk.

Regardless of the disaster prevention version, "self-help" is always important at every stage. For example, the Jishin Itsumo Project (2007) introduces the following comments of 167 HanshinAwaji Great Earthquake survivors with handwritten illustrations. They include some insightful ideas like; "In a disaster, you will realize that the habit of daily greetings among neighbors would be the best disaster mitigation more than survival kit and helmets", "It is more useful knowing what you can do with a single towel rather than preparing a large number of disaster-prevention goods." These comments suggest that everyday habits in the life of a community may contribute to lowering disaster risks more than just ordinary preparation for disaster situations. In fact, "In the Great Hanshin-Awaji Earthquake, $77.4 \%$ of the victims were estimated to have been rescued by the residents of their neighborhood" (Kawata 1997, p. 8). The acts of mutual help like this can be established only with the habitual exercise of self-help.

There is a serious warning about the potential risk of Nankai megathrust earthquakes in the western Japan area where we are based, various disaster drills are implemented in every community. Under the disaster prevention 4.0, various disaster prevention drills are expected to reduce the risk of disasters with constructing hardware. The question is how we can make these drills diverse enough to cover a wide range of methods, subjects and objects. Particularly in areas where there are the mega-disasters warnings, it is important to carry out awareness-raising drills not only to prevent disasters but also to mitigate the damage. For this reason, the methods of the present disaster drills should be reconsidered and new styles or concepts of disaster prevention and mitigation drills should be explored.

In Japan, especially after the Great East Japan Earthquake, disaster drill assuming an emergency situation in daily life is one of the hot issues. For example, Katada and Kanai (2016), who have been engaged in disaster education for 8 years at elementary and junior high schools in Kamaishi City, a coastal area of Iwate prefecture, advocates the importance of "making one's own decision and running for one's own life" from the result of a survival rate which was amazing $99.8 \%$ on March 11, 2011 (called "The miracle of Kamaishi"). Also, Nagata (2013), who developed a new disaster training method "Iza! Kaeru Caravan" for the 10th memorial event in Kobe since the Great Hanshin-Awaji earthquake, said; "In order to save our lives, it is important to come up with appropriate practices for the community residents, not just adopting the finished products." Of course, after the Great Hanshin-Awaji Earthquake, the importance of such disaster prevention efforts has been advocated. For example, Watanabe et al. (1999) suggested that simple activities such as adults and children walking together in the community would be a good idea to develop safe and secure community. He summarizes this kind of approach as "Preventing Disaster WITHOUT Saying Disaster Prevention".

\subsection{Purpose}

Various drills have been conducted all over the world as preparation for disaster (e.g. Simpson 2002). Also, empirical studies on disaster drills at hospitals have been reported as risk management for human life (e.g. Kaji et al. 2008). In the United States, there is also a report in which the importance of disaster prevention education in the school environment has been reconfirmed based on the results of the shakeout training (Showstack 2012). There is also an empirical research by 
using logical models to classify the framework of disaster drills for enhancing resilience, which has confirmed the importance of disaster drills based on the lessons learned from the Great Hanshin-Awaji Earthquake and the Great East Japan Earthquake. (Johnson et al. 2016).

In recent years, there are some disaster prevention programs with residents' involvement in Japan. Iwahori (2017) engaged in disaster education programs based on legitimate surrounding participation theory. Sun et al. (2014) developed a single person drill with smartphone applications and found the following three types of negative attitudes among the local residents who received a tsunami warning: "overly pessimistic", "excessively optimistic" and "overly dependent" (p.32). Therefore, we focused on the creation, maintenance and development of resilience (e.g. Aldrich 2012) to effectively respond to varying attitudes among the participants during and after our workshop. By doing so, we explored the way to build good human relationship among the residents in the community from the pre-disaster stage.

However, even though the importance of preparing for disaster prevention is recognized, and as more efforts have been expended for it, the "counter productivity" (Cayley 1992), a technical term by Illich, tends to increase in disaster drills if they are not properly designed. For example, many of disaster drills carried out in the community are led by the administration, and even in the trying out of fire extinguishers, the role of the participants is often predetermined according to a fixed scenario. Therefore, the participants tend to be divided into two groups; one is those who can experience disaster drills firsthand and the other is those who stand aside to watch. This disparity might take away the opportunity from the participants not only to share the experience of fire drills but also to develop interpersonal relationships among the community members based on mutual trust.

In this research, therefore, it is intended to explore how the disaster prevention and mitigation framework could be more comprehensive, that is, how we could establish a new style of the drill that will not only involve disaster preparation exercises but also facilitate active collaboration and participation among the community members. For this aim, we conducted a workshop called "Okaimono de Bousai (OdB): Disaster Prevention through Shopping" as an action research and made analysis of the comments and episodes obtained from its participants. Since this workshop was planned as an opportunity to raise awareness of disaster prevention as daily habits, it should not be regarded as just a unique, interesting 1-day event to enjoy. Therefore, the participants were encouraged to be engaged in active communication through SNS group posting from the preparation stage. By referring to the ideas and concepts introduced in "preparation for disaster in daily life" (Nagata 2013), we also explored an effective way of planning, implementation, and evaluation of the program with diverse entities in the community.

The remainder of this paper is organized as follows: In the next section, the research method regarding the following 3 aspects is described: 1. the details of collaboration between the researchers and participants for qualitative analysis of this participatory action research; 2 . the theoretical framework used for analyzing the research outcome through phenomenological descriptions; and 3. introduction of social, cultural, economic, and historical background of Kusatsu City, which was chosen as a research site. In section 3, the outcome of our collaborative practice is discussed by showing ethnographical descriptions, including the result of text analysis of SNS communication. And in the final section, characteristics of the community created by our participatory action research are discussed in terms of its effectiveness in disaster prevention. In doing so, we refer to the activity theory and compare the characteristics of our workshop with those of existing disaster prevention drills. The prospect for building future community network 
for better disaster prevention and mitigation is also discussed.

\section{METHOD}

\subsection{Transition from collaborative practice to action research}

This research is a qualitative research consisting of collaborative practices and participatory action research. As the prior studies of Atsumi (2009), Atsumi and Goltz (2014), Atsumi et al. (in press) show, we believe that collaborative practice should be started before participatory action research. Both of them are carried out for "betterment" at the practice site and the result is a joint production of researchers and practitioners (Sugiman 2016). We considered this collaborative aspect particularly important because "scientific harassment", as the 1st author calls it, should be carefully avoided. ${ }^{3}$

This research/practice was triggered by the 2 nd author making a case report in the community at a public research conference at the university where the 1st author works. On March 28, 2016, the 2nd author reported the practice called "Bousai Onigiri Day (BOD):Rice ball day for interaction and communication as disaster prevention" with the members of "Kusatsu Mirai Project (KMP)" and an officer of Kusatsu municipality. KMP is a citizen's organization for creating a good future in Kusatsu City, Shiga Prefecture, Japan. This practice is a monthly lunchtime activity to eat rice balls and talk together on every 17th, the date of occurrence of the Great Hanshin-Awaji Earthquake (January 17). It started on June 17, 2015. At that research conference, the 1st author made comments and questions from his revitalization support activities in the Hanshin-Awaji Great Earthquake, the Great East Earthquake and 2016 Kumamoto Earthquake. Later, the authors exchanged views and opinions by using a Social Networking Service (SNS).

The turning point was a brainstorming conducted on October 26, 2016 with colleagues of the 2nd author about community development on the theme of disaster prevention and mitigation in the future Besides the BOD, KMP was seeking ways to make local residents motivated for disaster prevention and mitigation. In that brainstorming, the 1st author introduced his case of the past initiative planned by his institution. That was the "Disaster Prevention Goods Shopping Contest" conducted at the large-scale shopping center in Ibaraki City, Osaka Prefecture on April 18, 2014 (see Figure 1). From that day, the interests of two authors who have long engaged in communitybased disaster prevention and mitigation efforts overlapped and the problem of participatory action research became clearer.

\footnotetext{
3 The term "scientific harassment" was created by the 1st author based on the idea of "damage on the research site" by Miyamoto (1972). It is similar to academic dishonesty, a self-serving way of conducting the research to distort its process and/or results as desired by the researcher. In our research, such an act, whether intentional or not, would spoil the integrity of the entire practice, particularly because it betrays goodwill of the participants. For this reason, the 1st author regards it as a type of harassment against the participants.
} 


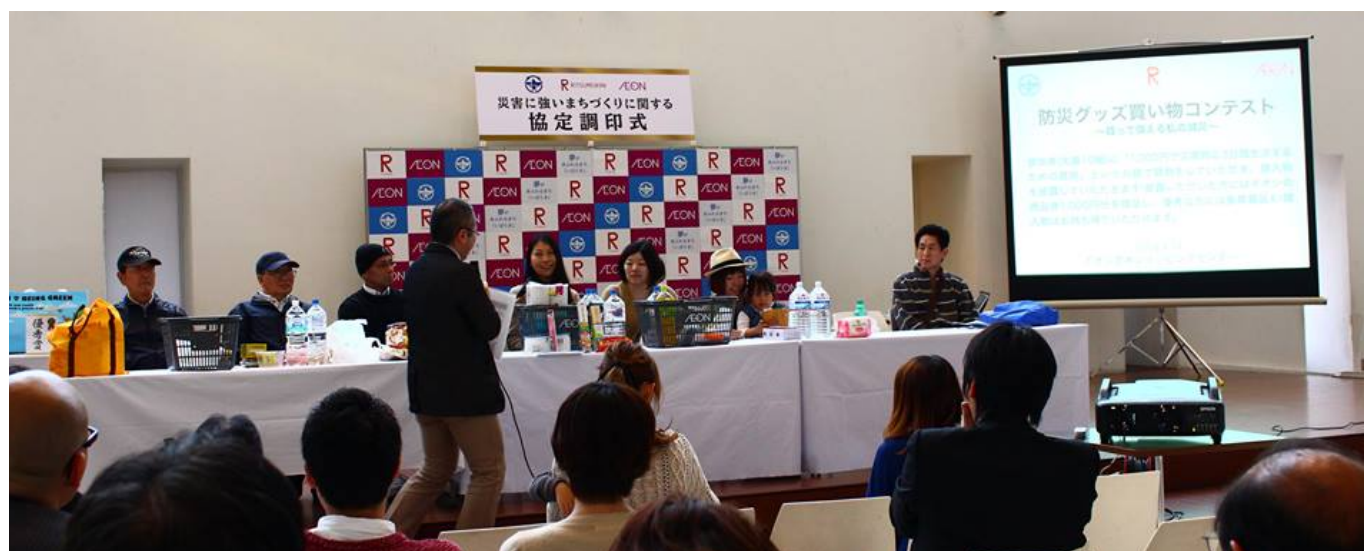

Figure 1. Disaster Prevention Goods Shopping Contest

(Photo taken by the Office for the Support of Post-Disaster Recovery, Ritsumeikan Trust) ${ }^{4}$

\subsection{Theoretical framework}

From the stage of collaborative practice, researchers took notes and sometimes reported their practices in blogs, SNS, etc. As Emerson et al. (1995) suggests, those notes become "Ethnographic Fieldnotes" of their fieldwork as the questions are examined throughout the course of the action research. Also, through this theoretical framework, we made efforts to create a good mutual relationship between researchers and practitioners to accumulate materials for analysis. Furthermore, we kept photographs and videos by obtaining consent from people who met on the site and used them as materials for analysis.

Because SNS was actively used in our collaborative practice, we chose "co-occurrence network analysis" (e.g. Osgood 1959, Danowski 1993) for group posting with the approval of the users. For the analysis, this paper used KH Coder which is a free software developed by Koichi Higuchi, a Japanese sociologist, for quantitative content analysis of text data. As mentioned by the developer Higuchi $(2013,2016,2017)$ in English, co-occurrence network is "a common technique in quantitative content analysis field" and "content analysis is a very common technique for analyzing media messages in the sociological field". As described later, the analysis of the group posts in the free communication application "LINE" was made.

After the text analysis, we endeavored to make phenomenological descriptions by overviewing a series of processes with "Activity Theory" (Engeström 1987). This theory is framed on the triad of subject, object, and mediating artifact developed from the triangular model of "a complex, mediated act" by Vygotsky (1978 p.40). Engeström (1987) focused on further intermediating factors. In accordance with Sugiman's (2016) interpretation, human activity assumes that community of practice mediates the relationship in some acts between subject and object, and that triangle relation is set as the basic system of activities. Then, human activity is treated with the

\footnotetext{
4 TNot only this photo but all the photos in this paper were obtained with the permission of participants. This photo was posted at the official Facebook page of the Office for the Support of Post-Disaster Recovery, Ritsumeikan Trust. The 1st author was one of founders of the office and a planner and coordinator of the contest. (https://www.facebook.com/fukkoR/photos/a.256753397703227.65923.250458264999407/753224371389 $458 /$ )
} 
subsystem (tools, rules, a division of labor) which encompasses three elements constituting the basic system of activity. Figure 2 shows the structure of human activity. With this comprehension, this paper explores the ideal way of creating and managing the programs to prepare for and mitigate disaster risks in daily life through participatory action research. In doing so, we adopted co-occurrence network analysis for SNS and activity theory to the whole process of our collaborative practice.

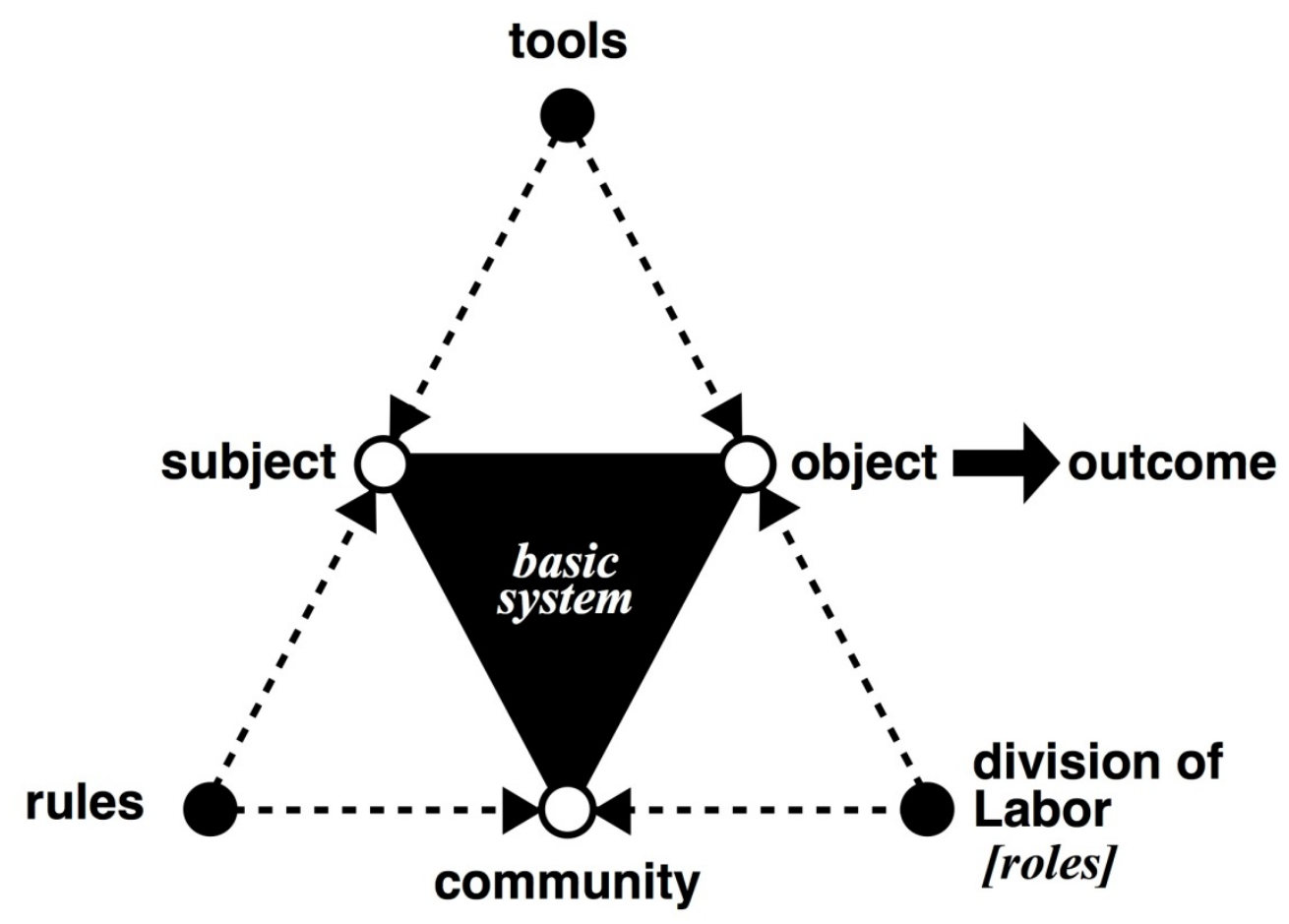

Figure 2. Engeströrm's (1987) Activity Theory

(Simplified according to Sugiman's (2016) interpretation. italic, paint, dot line modified by the1st author)

\subsection{Overview of the sites}

KMP, which worked in collaborative practice with the 1st author, is a non-profit organization in Kusatsu City, Shiga Prefecture. In March 2007, the 2nd author founded a childcare circle in her school district, which was later incorporated in March 2016. Despite the nation-wide population decline in Japan, Kusatsu City is one of the rare municipalities that have not experienced a declining population. The population exceeded 100,000 in 1995, and 130,000 in 2010. According to "Kusatsu City Population Vision" (Kusatsu City 2015), this population expansion was brought by the improvement of train access to the Osaka-Kyoto line in 1970 (the Kusastu population then was only 46,409), the redevelopment of the station front area in the 80s and the development of a new city center on the south side of Kusatsu City in the 90s.

One of the factors that facilitated population growth in Kusatsu was the opening of the new campus of Ritsumeikan University in 1994. Back then Ritsumeikan University, with its main campus located in Kyoto, was seeking a new education and research site mainly for its science and 
engineering departments. In the 1980s, it was coincided with the intention of Shiga Prefectural Office and the Kusatsu City Office to promote social, economic, and cultural development. And the official announcement of opening the new campus was released on September 19, 1989. The new campus (Biwako Kusatsu Campus: BKC), which initially opened only with 5,000 students, developed to a scale of over 10,000 students in the 2000s. In addition, the new train station was opened in 1994 and in March 2011, the new express train also started making stops, which enabled the passengers to move to Kyoto in 20 minutes and to Osaka in 50 minutes. Apartments built around the new station were purchased mainly by child-rearing families. It was in this social background where the needs for KMP activities arose.

The main field of collaborative practice was the large-scale shopping center which opened in the suburbs of Kusatsu on November 26, 2008. Its total area is 165,410 sqm, the total floor area is about $177,000 \mathrm{sqm}$, and the number of stores is 187. Approximately 4,300 parking lots are prepared and it is regarded as one of the largest commercial facilities in western Japan. Kusatsu municipality signed an official agreement with this shopping center for future collaboration and cooperation in this newly developed region. It was concluded on October 12, 2008. Prior to this agreement, Ritsumeikan University also concluded an agreement about social and cultural contribution through research and education with Kusatsu municipality on November 6, 2003. In this way, not only local government but also various private organizations are taking a positive attitude to establish good mutual relationships within the community.

\section{CASE}

\subsection{Workshop through Shopping for Disaster Prevention}

As mentioned above, the workshop in Kusatsu was modeled after the prior event titled "Disaster Prevention Goods Shopping Contest" held in Ibaraki City on April 18, 2014. And on October 26, 2016, the 1st and 2nd authors conducted a brainstorming in Kusatsu and created an organizing committee with KMP members, an officer of Kusatsu City Office and some voluntary students of Ritsumeikan University. It was planned by frequent exchange of opinions among the stakeholders (i.e. KMP members, an officer of Kusatsu City Office and students; Mr. Ueda and Ms. Toda) online and a total of three physical meetings. Coincidently the venue where we planned for the workshop was the same shopping center chain as the one where the 1st author practiced in Ibaraki. Due to this coincidence, decision making process was successful among the members and the store manager of AEON Mall Kusatsu. The planning summary was completed on January 26, 2017, and it was accepted without objection from the shopping center. The workshop was named "Okaimono de Bousai $(\mathrm{OdB})$ : Disaster Prevention through Shopping" and held in the morning of February 11th (National Foundation Day, a national holiday). Because it was the first trial in Kusatsu City, we limited the participating capacity to 10 persons, and the 2 nd author carefully selected people from various social and economic groups.

Table 2. Timetable of "Okaimono de Bousai (OdB)" in Kusatsu on Feb.11th

\begin{tabular}{cl} 
Time & Contents \\
\hline $10: 30$ & Opening \\
\hline $10: 35$ & Briefing of purpose \\
\hline
\end{tabular}




\begin{tabular}{ll}
\hline $10: 55$ & Start Shopping / Planner Talk Session [For those who do not want to buy] \\
\hline $11: 25$ & Show off purchased items \\
\hline $11: 55$ & Review and awards \\
\hline
\end{tabular}

On that day, the workshop proceeded according to the timetable in Table 2 by the flow shown in Figure 3. Participants were instructed to buy within 30 minutes a maximum of 2,000 yen of supplies they considered "Necessary to survive for 3 days after the occurrence of a large earthquake". This 3-day standard is a number that can also be seen in the proposal from the expert panel of the Japanese Government (The Cabinet of Japan 2016) as mentioned earlier. Of course, if a disaster occurs, mutual or public aid would be hastened to provide support internally or externally, but the 3-day standard is regarded as a criterion to encourage self-help to survive the "Golden Time" (72 hours), after which a high probability of death is expected due to dehydration symptoms.

Even in this well-designed workshop, participants are divided into two groups. It was because of the Japanese mentality that inhibits some of the participants from actively performing in public (e.g. Imamura et al. 2010) In fact, when we announced that some participants might be asked to give a brief explanation about their shopping experience, some of them preferred to remain as audience and would rather not participate in shopping because they felt embarrassed to speak in front of the group. We regarded these participants as "casual" participants in contrast to "active" ones, who willingly participated in the whole process of shopping and shared their story. For "casual" participants, we introduced a mini lecture in the workshop so that nobody would waste their time waiting while active participants were shopping. A mini lecture was coordinated like a talk show or a stand-up comedy to create a relaxing atmosphere where two of the organizers introduced their own practical experience. It was interesting to observe that thanks to this adjustment, some of the casual participants became slightly more active and started showing more interest in this activity. 


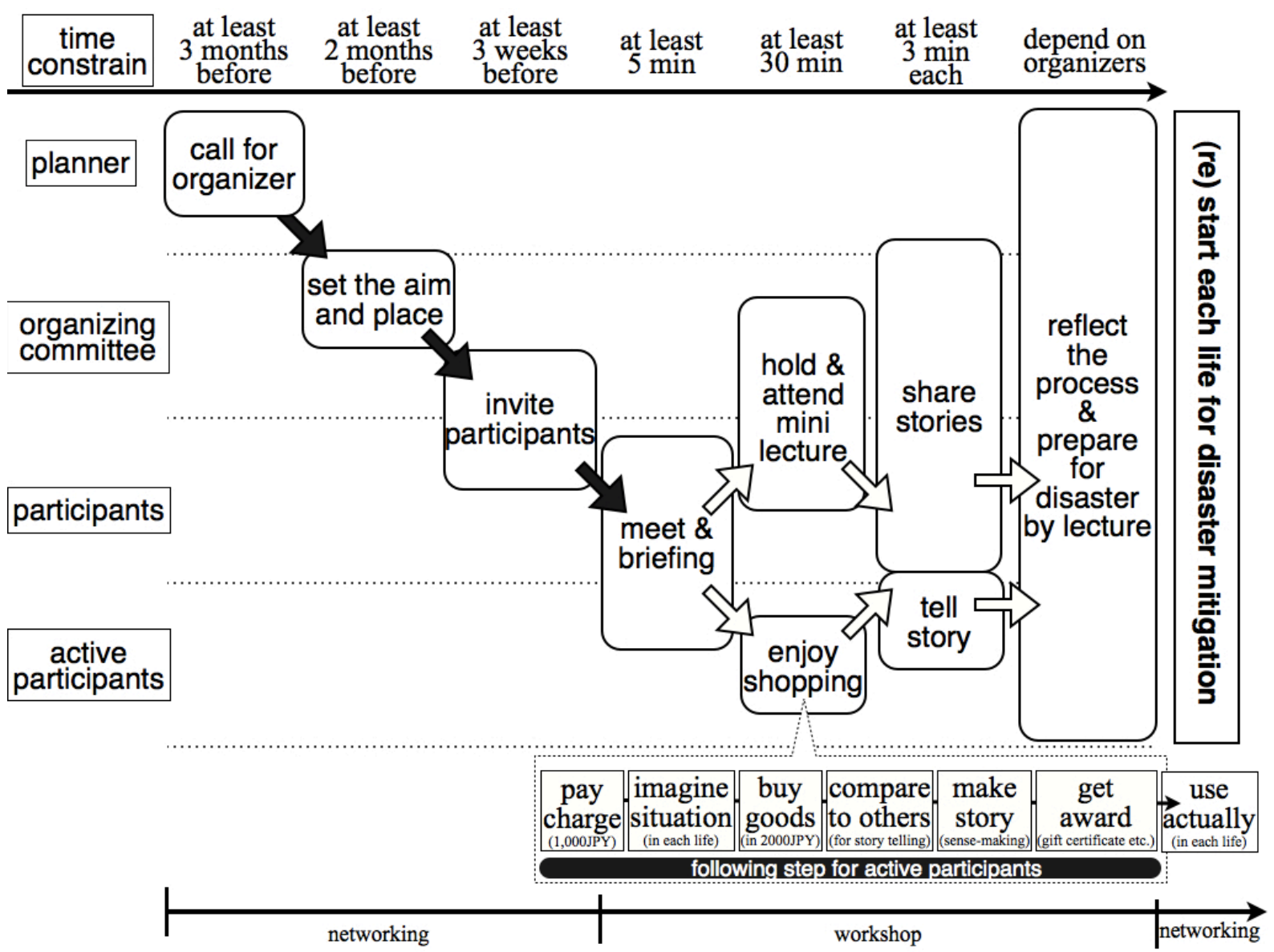

Figure 3. Workflow of a Workshop through Shopping for Disaster Prevention(Created by the 1st author)

When the active participants came back from shopping, we started a session where the participants were asked a question; "How can you prepare for 3 days after a disaster?" By sharing this question, all the participants, whether casual or active, came to have a common goal of "preparing for disasters in their daily lives". The active participants introduced their stories within 3 minutes each, as to what kinds of disasters they assumed and what kind of products they purchased to survive in the situation. The purchased goods of 10 people are as shown in Table 3. After sharing the story, one of the organizers facilitated the reflection on the entire process in the wrap-up session and asked all participants to think again of how to prepare for disaster mitigation. At the same time, the organizer and the store manager commended the practitioners with remarkable creativity and imagination for disaster situations. (See Figure 4). Finally, all active participants received a gift certificate of 1,000 JPY for next shopping from the shopping center, and the organizer distributed to all the attendees a list of the disaster prevention goods created by the survivors' organization of the Great East Japan Earthquake. Active participants were expected to actually use the purchased goods from that evening and report on their experience in the seminar to be held 6 days later.

As the disaster prevention would be incomplete if the participants only had the knowledge or instructions about the disasters, they need to make it "habitualized" in their daily lives through actively getting involved in practical experiences in workshops or evacuation drills. To facilitate 
this involvement, we decided to introduce SNS to share the experiences of the participants after the workshop. We discussed this SNS communication during the follow-up seminar held 6 days after the workshop. With casual posting on SNS, all participants and staff could deepen the wisdom of survival by exchanging ideas of the real use of the purchased items.

Table 3. Purchased goods by active participants in "Okaimono de Bousai (OdB)"

\begin{tabular}{|c|c|c|c|c|}
\hline No. & Attribute & Gender & Sum & Goods (amount) \\
\hline 1 & School Child & male & $¥ 1,685$ & $\begin{array}{l}\text { 2I Water (3), Fruit Granola (1), Tuna Can (4), Wet Tissue in Box (1), } \\
\text { Gum Tape (2) }\end{array}$ \\
\hline 2 & School Child & female & $¥ 1,201$ & $\begin{array}{l}\text { 2I Water (1), Rice Cracker (1), Energy Gerry (2), Sweet Cone Can (1), } \\
\text { Food Can (1), Pop cone (1), Chocolate Bar Bag (1), Chocolate Plate } \\
\text { Snack (1), Potato Chips (1), Gummy Candy Bag (1) }\end{array}$ \\
\hline 3 & Univ. Student & male & $¥ 1,005$ & $\begin{array}{l}\text { 2I Water (1), Vitamin Candy (2), Plate Chocolate (2), Bath Towel (1), } \\
\text { Kitchen Wrap (1), Mini Square Cushion (1) }\end{array}$ \\
\hline 4 & Univ. Student & female & $¥ 1,247$ & $\begin{array}{l}\text { 2I Water (2), Rice Bowl (3), Yakitori Can (2), Sardine Can (Miso) (1), } \\
\text { Sardine Can (Ginger) (1), Mango Gerry Drink (1), Milk Chocolate bag } \\
\text { (1), Ring Donuts Bag (1), Gum Stick (1) }\end{array}$ \\
\hline 5 & Univ. Student & female & $¥ 1,201$ & $\begin{array}{l}\text { 2I Water (1), Cheese (1), Cut Gauze (1), Wet Tissue (1), Plastic Tape } \\
\text { (1), Rain Coat (1), Toy Bat and Ball (1) }\end{array}$ \\
\hline 6 & Entrepreneur & male & $¥ 1,216$ & $\begin{array}{l}500 \mathrm{ml} \text { Water (4), Chicken Egg Can (1), Yakitori Can (Egg \& Radish) (1), } \\
\text { Yakitori Can (Citron Pepper) (1), Energy bar (Chocolate) (1), Energy bar } \\
\text { (Blueberry) (1), Wet Tissue (1) }\end{array}$ \\
\hline 7 & Housewife & female & $¥ 1,933$ & $\begin{array}{l}\text { 2I Water (1), Low fat Bread Snack (1), Potato Snack (1), Diaper (46pcs) } \\
\text { (1), Infant Hip Wiper (2), Disposal Plastic Cups (1), Food Preserve Bags } \\
\text { (1), Kitchen Wrap (1) }\end{array}$ \\
\hline 8 & Housewife & female & $¥ 1,700$ & $\begin{array}{l}\text { 720ml Vegetable Juice (1), Rice Bowl (3), Spaghetti (3), Meat Source } \\
\text { (1), Miso Ramen (5pcs)(1), Rise Cracker (1), Wet Tissue (1), Mask } \\
\text { (30pcs) (1), Trump (1) }\end{array}$ \\
\hline 9 & Retired & male & $¥ 1,893$ & $\begin{array}{l}\text { 2I Water (2), Instant Mixes (chicken/egg) (1), Instant Mixes (Chinese } \\
\text { taste) (1), Tuna Can (1), Mackerel Can (1), Instant Noodle (3), Instant } \\
\text { Rice (5pcs) (1), Flash light (1) }\end{array}$ \\
\hline 10 & Executive & male & $¥ 1,907$ & $\begin{array}{l}\text { Biscuit (24pcs) (1), Embryo Biscuit (24pcs) (1), Earplug (1), Eye Mask } \\
\text { (1), Mask (5pcs) (1) }\end{array}$ \\
\hline
\end{tabular}

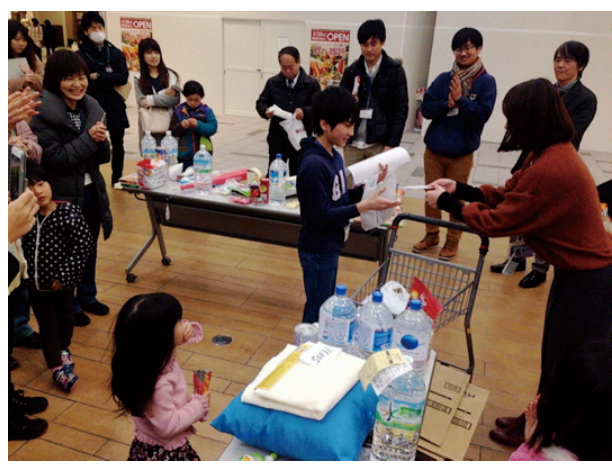

Figure 4. Recognition in "Okaimono de Bousai (OdB)" in Kusatsu on Feb.11

(Took by the 1st author, 11th February 2017)

3.2 Sharing of experience at the follow-up seminar

The shopping workshop for disaster prevention was the first experience for KMP. KMP had 
already been sharing the wisdom attained from its own disaster prevention drills using SNS. They adopted an approach they called "guerilla disaster prevention drill"s.

The 1st trial of "guerilla disaster prevention drill" was held on 29 March 2016, which was the next day of the research conference in Kusatsu, and 17 members of KMP joined this drill. It was intended to have the participants think about what kind of inconvenience they might suffer when water, gas, electricity, and toilet cannot be used at home. They went through a simulation exercise in which they actually didn't allow themselves to use water, gas, electricity, and toilet for 12 hours at home with cooperation of their family. Through this simulation, they learned what types of problems would arise during the time before they are evacuated to a shelter.

Following this drill, a shopping workshop was held on February 11, 2017, where 24 people joined and the 2nd author asked them to use the purchased items for 3 days from the evening of the workshop day and report about their experience. 960 comments were posted in 3 days. A voluntary student from the organizing committees analyzed them and reported the results in the seminar hosted by Kusatsu City on February 17. Also, two active participants agreed to make a presentation at this seminar.

This seminar titled with "From Disaster Prevention to Disaster Reduction" was facilitated by the 1st author. It was held at the Urban Design Center Biwako Kusatsu (UDCBK) as the 9th seminar of a series of "Future Creation Seminars" hosted by a think-tank organization "Kusatsu Future Research Institute" of Kusatsu municipality. UDCBK's senior director who served as a moderator said, "we want to have a chance to reevaluate the dominant stories and think about alternative stories for saving our lives". Approximately half of the 2-hour seminar was used for reporting on the "guerrilla disaster prevention drill".

In the report of the "guerrilla disaster prevention drill", one housewife (Ms. Kaori Miyamori) holding a 1-year-old child talked about her experience of using "diapers" in an emergency situation. In her presentation on February 11th, she said "Because a 1-year-old child has a small urination volume, the diaper could afford much more discharges. Adults may reuse it in a disaster." "Guerrilla disaster prevention drill" required its participants to actually use the items after the workshop by assuming the real disaster situation. So what did she do? The participants had already shared it with LINE, and she shared her experience as follows.

"I have a 1-year-old son, so I bought a diaper at the very beginning of the workshop. Toilets are quite an important issue in a disaster. Because a diaper will be precious in such a situation, I want to use each piece as much as possible. But the children's skin is very delicate, so it is not

\footnotetext{
5 To avoid confusion, the word "guerilla" in this KMP drills should be clearly distinguished from the negative use as in "guerilla rainstorm", a term that came into frequent use around mid-2000s in Japan, referring to unexpected, extreme heavy rain caused by climate change. Quite contrary to that, "guerilla" as used in KMP's drill is a positive one. It refers to a new style of the disaster drills. Typically, in conventional disaster prevention drills in Japan, the entire procedures are often predetermined with ready-made instructions based on fixed scenarios. The organizers and even participants can predict what would happen during the drills. On the other hand, KMP's "guerilla drill" tries to have its participants encounter a number of unpredictable disaster situations with no fixed scenarios, which is felt like fighting "guerilla warfare" by the participants. It is this unpredictable nature that they call "guerilla". It helps the participants think and learn for themselves more realistically about potential disaster situations that might fall on them suddenly and unexpectedly in their real lives.

${ }^{6}$ Both presenters' narratives were described in KMP blog as open to the public in below URL. https://ameblo.jp/umareru-minakusa/entry-12249390919.html
} 
a smart way of using it. However, at the presentation, I was reminded that a 1-year-old child has a small urination volume, so I thought that diaper could be reused by adults.

Well, I tried out an experiment. As a result, the diaper used several times was possible to absorb up to $800 \mathrm{ml}$ of water. And, after that, I, myself, tried a diaper used by my son. It was not an indirect experiment like taking urine in a cup. I actually did use the diaper myself. Consequently, the used diaper of my son was found able to be reused by adults.

Honestly, I was really embarrassed. But through this hands-on trial, I could imagine the terrible situation in a disaster and I gave my courage to do it."

Another person was a retired male in his 60's (Mr. Hirokazu Yamamoto). He introduced his struggle to eat instant rice without using a microwave oven. Just like Ms. Miyamori, he made a presentation at the workshop in which he said; "Because my house is served by propane gas, it would be possible to boil hot water and eat instant noodle even in a disaster. I chose to purchase packed rice also, but that was a mistake. I thought this kind of rice could be eaten directly. Some of the participants suggested to me that I must eat it by using a microwave oven." He also made experiments to eat it delicious even without electricity. The result was also reported in LINE, and he presented it on February 17 seminar as follows.

"When I imagined a disaster, I thought the most important thing was securing my food. First of all, I purchased water, then instant noodles. I was thinking that if I was to be in the situation where even propane gas is unavailable, I would burn some trees in my garden to boil water.

However, I did not know well enough about the instant rice. In fact, I believed I could eat it immediately with no need for warming. So, my challenge to find out how to eat it deliciously without warming was started. Before sharing my result, however, please remember that I do not recommend eating it without warming.

In SNS group, a kind member suggested: "How about pouring miso soup over it?" So I tried, but still bad. Finally, supposing that my house was partially destroyed, I made a fire in the garden and boiled the water. I stuffed instant rice in a plastic bag to heat it up. That produced a satisfactory taste."

Approximately 30 people participated in the follow-up seminar, and 21 questionnaires were collected. In the questionnaire comment section are found comments like "From now on I'll go shopping assuming there would be a disaster", "I realized that it is important not only to buy, but also to use actually." From these responses, we can see that shopping workshops and follow-up seminars have helped raise awareness of all participants and motivated them to think about how they could act appropriately in actual disasters. 


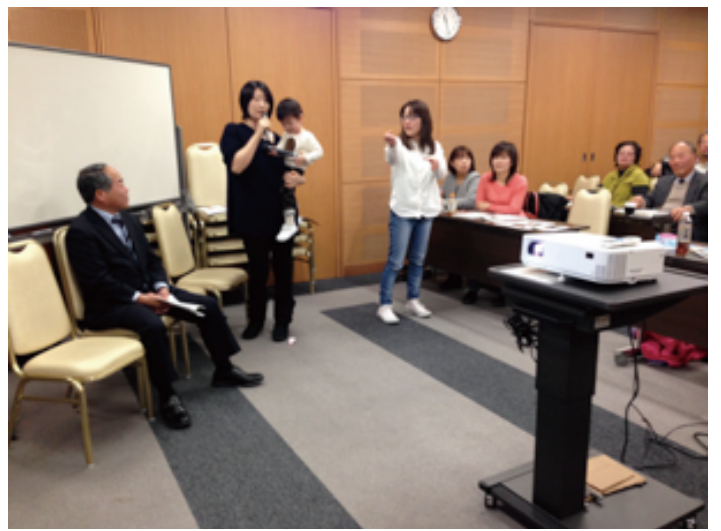

Figure 5. 2 active participants presenting their stories in the follow-up seminar (Photo taken by the 1st author, 17th February 2017)
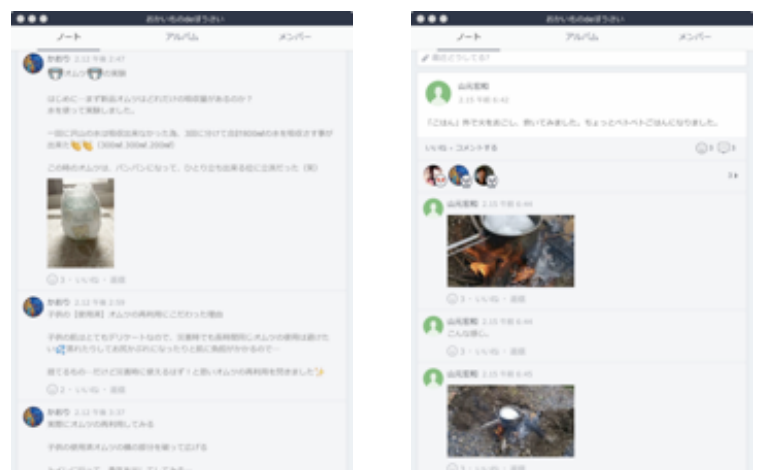

Figure 6. Challenge notes of 2 active participants posted on the SNS group (Left: Ms. Miyamori, Right: Mr. Yamamoto)

\subsection{Co-occurrence network analysis for communication on SNS group}

In order to examine communication dynamics on this workshop, we analyzed 2,585 posts on the SNS group during the period from February 11, 2017 to June 15, 2017. We set the ending date of our analysis on June 15 because a KMP member proposed another project starting on this date. As mentioned above, we used the KH coder for quantitative content analysis of text data in this study. To better analyze the posts, the 1st author formatted the text to unify the phrase, resulting in 800 sentences in 229 paragraphs. Emojis ${ }^{7}$ are frequently used in LINE, but KH Coder could not recognize them due to the limitation of character encoding. Also, stamps are frequently used in Line, but when the text is exported, LINE automatically converts the information and calls it [stamp] in the posts. So, our analysis includes only the number of posts for the stamp, not dealing with the meanings of each stamp at this time. The final targeted corpus database consists of 31,378 tokens of 3,280 word types.

The 20 most frequently used words are as shown in Table 4. Next, hierarchical cluster analysis of the words used more than 15 times was carried out by using the Ward method, with its result shown as in Figure 6. Hierarchical cluster reveals how these words are related with each other by referring to Japanese grammatical rules. Furthermore, Figure 7 shows the relationship between

\footnotetext{
7 "a digital image that is added to a message in electronic communication in order to express a particular idea or feeling." from http://dictionary.cambridge.org/dictionary/english/emoji
} 
how these words are used at the same time. This diagram shows the top 60 strongest cooccurrences as network edges.

From Figure 7, it can be seen that nine subgroups are interconnected. In Figure 6, the posts were divided into six groups, but for a more detailed analysis and interpretation, we used the structure of Figure 7. The main group is located in the center bottom. That consists of the core words about the impressions of the workshop. On the right side, there are words of deep insights from the participants, including an appreciation for the 2nd author as a president of KMP and reflection on her/himself as a participant in comparison with others. At the lower right, the group tied to the 1st author expresses their appreciation for preparation and contribution by the organizer and a shopping center. At the center right, the words indicate open feeling about the guerrilla disaster prevention drill, including some troubles.

Table 4. Frequently used words on SNS group of Shopping Workshop for Disaster Prevention

\begin{tabular}{lr}
\hline \multicolumn{1}{c}{ Words } & Frequency \\
\hline stamp (スタンプ) & 313 \\
\hline smile (笑) & 196 \\
\hline photo (写真) & 154 \\
\hline disaster prevention (防災) & 98 \\
\hline Dr. Yamaguchi (山口先生) & 61 \\
\hline guess (思う) & 60 \\
\hline person (人) & 58 \\
\hline Mr. Yamamoto (山元) & 39 \\
\hline today & 37 \\
\hline self (自分) & 37 \\
\hline say (言う) & 36 \\
\hline ask (お願い) & 34 \\
\hline Ms. Horie (堀江) & 31 \\
\hline note (ノート) & 30 \\
\hline join (参加) & 30 \\
\hline tomorrow (明日) & 29 \\
\hline cheese (チーズ) & 28 \\
\hline see (見る) & 28 \\
\hline eat (食べる) & 28 \\
\hline Mr. Ueda (ジュニア) & 27 \\
\hline
\end{tabular}




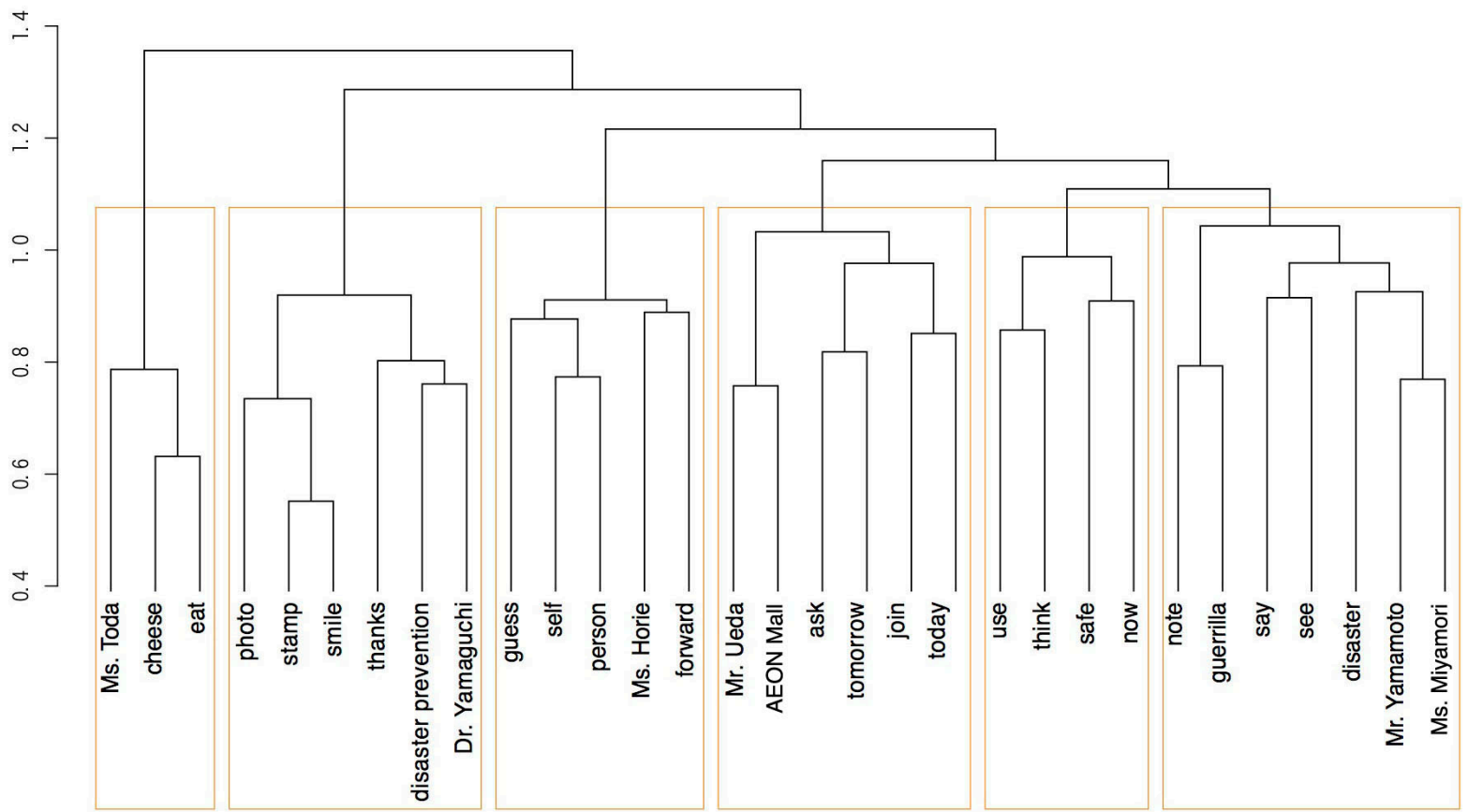

Figure 7. Hierarchical clustering on SNS group of Shopping Workshop for Disaster Prevention

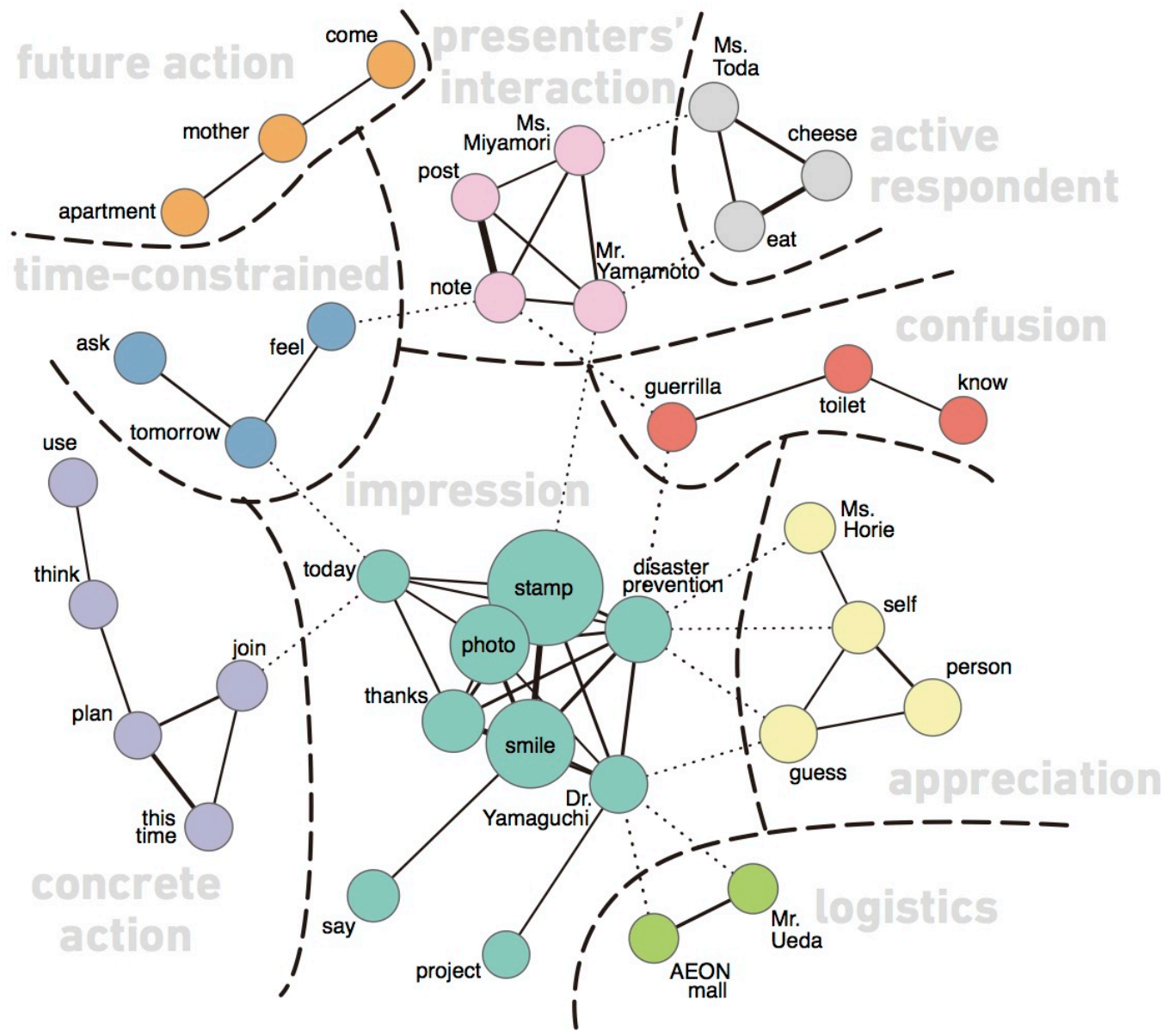

Figure 8. Co-occurrence network on SNS group of Shopping Workshop for disaster prevention 
Moreover, on the left side, it can be observed that some words are connected with the time elements. That is divided into 2 groups. One is communication pattern in which they exchanged questions with each other after the workshops; and the other is the expression of their future attitude towards disaster prevention based on their understanding of the objectives of the workshop. The top part is concerned with the presenter, and it indicates that the participants shared their experiment reports and posted frequently some comments and questions before/after the presentation. In addition, on the upper right, there is a story about how to eat cheese by a university student. This is treated as an independent group based on the hierarchical cluster analysis in Figure 6. because this suddenly became a hot topic among the participants due to an interesting way she bought the cheese. She loves cheese so much that she bought an amount that she alone would not be able to consume during the 3-day evacuation time of a disaster. For that reason, the participants actively exchanged better ideas to give her some suggestions through SNS communication. The way their communication was deepened was quite illustrative because it is exactly this type of mutual-help among the residents, rather than just receiving or waiting for external aid, that might mitigate the damage under real disaster situations.

Finally, the 3 words relationship of "apartment - mother - coming" is quite interesting. Table 4 indicates that these words are not frequently used, and Figure 7 shows that it is difficult to treat them as an important factor related to this workshop. However, what appeared in co-occurrence networks supports the fact that these three words are used at the same time and concentrated. Actually, after participating in the shopping workshop, some members conducted a participatory disaster prevention workshop on their own, in which they walked around with residents in the apartment to get to know more about their community.

Figure 7 had already been presented at IDRiM 2017 by a poster, but it was shared with LINE group members at $14: 37$ on July 20 before the presentation. We had received many comments immediately. During that day, 8 persons contributed 95 postings. Once again by looking at the whole, it can be seen that the four words at the end of the node are all verbs. If we consider the co-occurrence network as a word map for daily disaster prevention, the participants may carry the verbs "use, ask, know, say" shown in Figure 7 as a code of conduct after the workshop.

\section{DISCUSSION}

\subsection{Socio-cultural system in disaster drills}

In this collaborative exercise, we sought the ways to lead the participants to cultivate and develop a habit of disaster prevention to the extent that it will become a natural part of their daily lives. Typically, the main focus of the conventional disaster drills has been on how to protect people's lives by some evacuation training and instructions at the site. However, the workshop through shopping is characterized by its emphasis on having the participants actually assume real disaster situations they might face and think in more practical terms of how to avoid death right after a disaster or during their evacuation. Similarly, participants had the opportunity to think about effective preparation not by purchasing disaster relief goods but by thinking of how some daily commodities they regularly use could be utilized in actual disaster situations. In addition, by adopting the residents-centered framework in our workshop, even the motivation of the casual participants was positively affected by active participants, which is not expected to happen in 
traditional expert-based (see model "a" in Figure 8) drills.

In this research, in order to observe the process of this utilization, we analyzed the posts on SNS group used in collaborative practice and found that daily communication through disaster prevention was activated in the cyber community. Although it is impossible to prevent disasters personally, it is possible to mitigate the damage thorough the exchange of such daily communication. It should be emphasized again that the whole process of this participatory action research is designed not only to raise awareness of disaster prevention through shopping and lectures, but also to share the wisdom as to how the items of daily commodities could be utilized in actual disaster situations. This framework and its outcome were made possible by using SNS. Also, people who were unfamiliar with SNS also participated in the group, and one of them even accepted voluntary presentation at the follow-up seminar. These are impacts of the workshop.

We applied the activity theory (Engeström 1987) to examine the effect of the residents-centered disaster prevention workshop as a means of reducing disaster risks. First, we focus on the basic system of human activity in each style of disaster drills that are constructed with particular relationship among those involved in the drills. Next, we consider rules, tools and division of labor that establish relationships of three elements of a basic system: subject, object, and community.

a

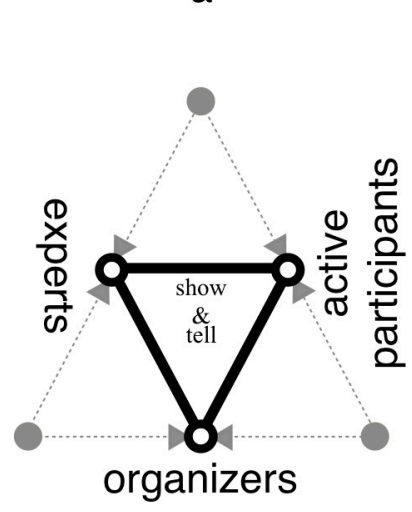

expert based

[typical drill] b

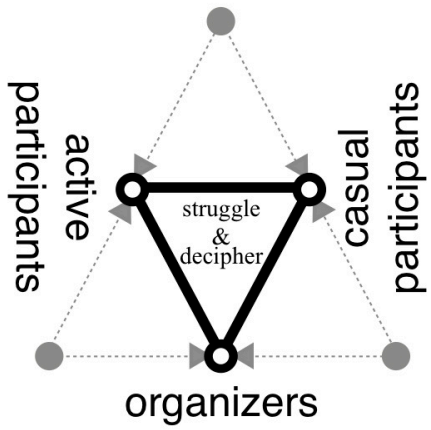

participants oriented

[resilient workshop]
C

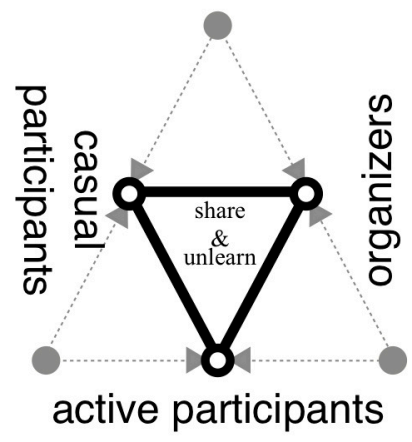

residents centered

[scenarios in guerilla]

Figure 9. Three states of basic system in disaster prevention drills

Figure 8-a is a tripartite relationship in traditional disaster prevention drills. Typically, experts demonstrate the drills with the organizer and collaborators, and participants are put into a position to be taught. The subject is often authority figures in local community or from government offices, with schools serving as cooperators. So, this type can be positioned as a basic system of the expertbased disaster prevention drills. In some cases, local residents may become active organizers, but

\footnotetext{
8 We introduced the activity system as "participants-centered" disaster drills in the presentation of IDRiM 2017. However, Dr. Norio Okada gave us his suggestion that due to the difference in the extent of experts' commitment, the three activity systems should be more clearly distinguished from each other. Therefore, in this paper, we redefined the three activity systems along with his concept "residents-centered". We would like to express our appreciation for his advisable comments here.
} 
those who are rather indifferent tend to be over-reliant on such enthusiastic residents.

Figure 8-b is a tripartite relationship in nontraditional disaster prevention drills. Similar to our collaborative practice, active participants struggle together to enhance community resilience under the organizer and collaborators, and the casual participants can also deepen their understanding. This can be positioned as a basic system of participants-oriented disaster drills. This composition is also true in "Iza! Kaeru Caravan", a disaster drill practiced by Nagata (2013). This drill is combined with toy exchange bazar, originally started in 2005 as a memorial event for the Great Hanshin-Awaji Earthquake. Compared with the traditional expert-based drill, this style is definitely an improvement. However, since it requires extensive coordination and preparations among the organizers and its success depends on the leading skills of the organizer, it lacks the improvisational elements as can be seen the residents-centered drills of Figure 8-c.

In our study of shopping workshop, a tripartite relationship as in Figure 8-c was maintained by creating and revising scenarios for disaster situations. Due to unexpected comments posted by active participants on SNS (the "guerilla" style), the casual participants were put into a position where they had to make improvised actions with no predetermined scenarios, and their attitude and skills were shared with the organizers and collaborators. On the SNS, the comments and questions that were seemingly trivial often had vernacular value that affected the participants' actions and behaviors. In this practice, a bipartite relationship of subject-object is not fixed but frequently reversed, thereby enhancing the community support to foster the tripartite relationship. These are the significant characteristics of the residents-centered disaster drills.

Regarding the rules, tools, and division of labor in these three basic systems, the expert-based disaster drills (Figure 8-a) is conducted more or less in the following way; first, the organizers set the practice day in a timing as traditionally considered as appropriate, for example, the day when the participants can be reminded of the past disasters in Japan, such as September 1 (Disaster Preparedness Day), January 17 (day of Great Hanshin-Awaji Earthquake), March 11 (day of Great East Japan Earthquake), etc. The purpose of the program is focused on transmitting experts' knowledge on disaster prevention to local residents, often with the cooperation of local governments and schools. Therefore, the participants are put into a position to be taught and the cooperators into a position to supervise and check the understanding of the participants. The roles to perform during the drills tend to be clearly fixed for every participant. Because traditional instruments are still believed reasonable by many, the participants welcome the tools and ideas provided in the expert-based disaster drills, such as how to handle fire extinguishers (assuming fire), make sandbags (assuming flood damage), and make quick evacuation in groups (assuming large-scale and complex type of disasters such as earthquakes, tsunamis, fires) and so on.

In the participants-oriented disaster drills (Figure 8-b), organizers set the time and place according to the needs of participants and the participants take a responsibility for active commitment to the whole process. Therefore, the motivation of casual participants will be affected by the active participants and they may be effectively led to abandon their negative preconceptions about disaster prevention through program experiences and start their own actions to mitigate disaster damage. The organizers play the role of cooperators and facilitate communications among the participants to develop and introduce new ways to prepare for a disaster. Thus, the organizers and participants still have a clear role to perform in this type of the drill, too. However, unlike the traditional expert-based disaster prevention drills, the participants-oriented type is designed to introduce tools to make its participants enjoy more, such as a puppet show with a story to encourage mutual aid and a time trial event to find efficient and effective evacuation. 
The residents-centered disaster drills (Figure 8-c) are different from the above two types. It is more oriented towards community development among residents, and each element of the tripartite relationship of the basic system frequently changes its position. In this way, the participants can explore and learn from each other how to establish a good community more flexibly and practically. In our shopping workshop, even the casual participants took the role of main actors to report on their trial to use daily necessities under their own assumptions, and active participants encouraged their challenges and contributions. Active participants posted their comments on SNS frankly, promptly, and appropriately and the organizers reflected on their purposes and intentions of the drill to consider future possibility for the next practice with the residents. The active participants and organizers shared a common assumption; "we all are the comrades in arms searching ways to create a good community". Supported by SNS, they could share trial reports in a disaster environment, and by doing so, their vague knowledge was successfully turned into explicit knowledge. All elements of Activity System in three disaster prevention drills are summarized in Table 5.

\subsection{Residents-centered Disaster Mitigation Community}

We conclude that the shopping workshop at the large-scale shopping center is a program quite effective to reduce disaster risk for the following three points. Firstly, unlike traditional disaster prevention drills, the participants were not led to acquire "correct" knowledge from anything or anybody. Secondly, through purchasing of daily necessities and sharing individual stories, the participants could better assume a scenario in a disaster on their own. Thirdly, unlike the other participatory disaster prevention drills categorized as "participants-oriented", all participants and organizers had the opportunity to reconsider the way of their everyday life through communication on the SNS group, and co-created some common wisdom to survive a disaster.

The first point coincides with the finding of Iwahori et al. (2017) about experiential learning experience in earthquake observation. That was also based on a participatory action research in which the collaboration between experts and volunteer supporters worked effectively in the creation and development of a community of practice involving participants. They reinterpreted some concepts by Lave and Wenger (1991) like "legitimate" as "authentic", "peripheral" as "plural" and "diverse", "participation" as "accessible", to show that active participants would contribute to establishing a community of practice (Iwahori et al. 2017, pp. 3-4). Like Iwahori's research, our collaborative practice was also based on the experience of the actual disasters (e.g., the Great Hanshin-Awaji Earthquake, the Great East Japan Earthquake, the 2018 Kumamoto Earthquake), and tried to establish dynamic relationships among many participants. In this sense, Iwahori's reinterpreted concept of "authentic" is manifest in our choice of the experience (actual disasters), as well as that of "plural and diverse" in the type of a relationship created (involving many people). By welcoming anyone who was interested, and creating no wall between the organizers and the participants, our workshop was felt "accessible", too.

Table 5. Comparison of elements of disaster drills 


\begin{tabular}{|c|c|c|c|}
\hline & Expert-based & Participants-oriented & Residents-centered \\
\hline style & typical drill & resilient workshop & scenarios in guerilla \\
\hline activity & show \& tell & struggle \& decipher & share \& unlearn \\
\hline subject & experts & active participants & casual participants \\
\hline object & active participants & casual participants & organizers \\
\hline community & organizers & organizers & active participants \\
\hline $\begin{array}{c}\text { rules } \\
\text { of subject }\end{array}$ & $\begin{array}{c}\text { transform } \\
\text { their knowledge }\end{array}$ & $\begin{array}{l}\text { active commitment } \\
\text { to the whole process }\end{array}$ & $\begin{array}{l}\text { matching words } \\
\text { with deeds }\end{array}$ \\
\hline $\begin{array}{l}\text { rules } \\
\text { of community }\end{array}$ & $\begin{array}{l}\text { plan } \\
\text { at an appropriate time }\end{array}$ & $\begin{array}{c}\text { set time and place } \\
\text { according to the } \\
\text { needs }\end{array}$ & $\begin{array}{l}\text { encourage } \\
\text { challenges }\end{array}$ \\
\hline $\begin{array}{l}\text { division of labor } \\
\text { for community }\end{array}$ & $\begin{array}{c}\text { supervise } \\
\text { for understanding }\end{array}$ & $\begin{array}{c}\text { facilitate } \\
\text { communications }\end{array}$ & $\begin{array}{c}\text { response } \\
\text { frankly and promptly }\end{array}$ \\
\hline $\begin{array}{c}\text { division of labor } \\
\text { for object }\end{array}$ & $\begin{array}{c}\text { learn } \\
\text { correctly } \\
\end{array}$ & $\begin{array}{l}\text { abandon } \\
\text { their preconceptions }\end{array}$ & $\begin{array}{l}\text { reflect practice and } \\
\text { consider possibility }\end{array}$ \\
\hline $\begin{array}{c}\text { tools } \\
\text { mediated subject- } \\
\text { object }\end{array}$ & $\begin{array}{c}\text { traditional instruments } \\
\text { (e.g. fire } \\
\text { extinguishers) }\end{array}$ & $\begin{array}{l}\text { designed programs } \\
\text { (e.g. show, event) }\end{array}$ & $\begin{array}{l}\text { daily necessities, } \\
\text { trial reports etc. }\end{array}$ \\
\hline
\end{tabular}

Regarding the second point, the workshop created opportunities of "Bricolage" (Lévi-Strauss, 1962) for surviving a disaster. All participants obtained not only some goods for a disaster but also explicit and practical knowledge by actually using them. The 2nd author called this style of the drill "guerilla disaster prevention drill" because nothing is fixed or predetermined according to a set scenario. The experience obtained through this style of practice and communication would play a significant role a habit of disaster prevention among the participants. In addition, since such experience is not a part of a mere accumulation of given knowledge, it brings about a sense of personal security rooted in a common experience and trust among the members of the community.

As for the third point, the workshop was a "collective improvisation game" (Atsumi 2001) of disaster prevention including cyberspace communication, which can be regarded as an advanced practice of "disaster prevention WITHOUT saying disaster prevention" (Watanabe et al. 1999). With the spread of the Internet, approaches to disaster prevention drills have also become diversified (e.g. Sun et al. 2017). This study focuses on stimulating the revitalization of daily communication in the community to better assume real disaster situations by using an SNS group. The participants unfamiliar with SNS until this workshop also joined the group to co-create and share knowledge. They also made an active contribution to the presentation at the follow-up seminar. However, it should be noted that by conducting both shopping workshop and communication on SNS under the name of disaster prevention, we intended to make an effort NOT to separate the activities in disaster situations from those in normal daily life. In other words, by conducting a "disaster mitigation workshop INTENTIONALLY saying disaster prevention", we intended to improve participants' everyday life by leading them to develop a habit of constantly imagining extraordinary life situations in disasters.

In this way, a residents-centered disaster drill provided its participants opportunities to make a reasonable preparation for a disaster, as well as a new custom to ask themselves repeatedly whether they are having enough communication with the residents of their community in their daily lives. In addition, while it is certainly important to prepare for a disaster, we should also be careful not 
to prepare too much. In other words, we should be attentive to a paradox that the more efforts are made only by some specific individuals, the greater the motivation gap could be among the members of the community. In such a circumstance, knowledge and ideas, or even kindness and thoughtfulness of the well-intended individuals may not be accepted by other members of the community. In order to create a resilient community, it is important to involve all community members to share appropriate roles, rather than expecting only some enthusiastic individuals to play all major roles.

We are pleased to realize that even after more than half a year since the end of the follow-up seminar, participants and organizers are still posting their thoughts and comments frankly and continuously on the SNS group. Circle activities on voluntary specific themes, such as disaster prevention activities in apartments and evacuation drills of children with allergies, have also begun. Thus, this study is just an early stage of participatory action research for community-based disaster reduction activity. We will continue our effort to develop, practice, and evaluate programs for the empowerment of knowledge, skills and attitude for both "serving aid" and "receiving aid" in the community, instead of just taking conventional measures like distributing the list of disaster prevention goods. Through such efforts and practices, we are sincerely hoping that the residents of the community will create a resilient future.

\section{ACKNOWLEDGEMENT}

This research would have been impossible without active participation of all the people involved in this collaborative practice. Specifically, the members of Kusatsu MIRAI Project (KMP) and AEON Mall Kusatsu provided generous support in our disaster drill workshop through shopping. In addition, at the follow-up seminar of the workshop, Mr. Tatsuo Mizouchi, senior director of the Urban Design Center Biwako-Kusatsu (UDCBK), extended his tremendous contribution. Also, in uplifting this collaborative practice to a level of action research, detailed description by Chie Ooe's contribution in KMP blog gave beneficial reflection to the authors. We would also like to thank Mr. Shoichi Maruta, full-time lecture of English at Ritsumeikan University, for his assistance in revising English grammar and expressions. Lastly, we wish to express our heartfelt gratitude to all those involved in this project for their wonderful support and cooperation. This work was supported by JSPS KAKENHI Grant Number JP26780485.

\section{REFERENCES}

Aldrich, D. (2012) Building Resilience: Social Capital in Post-Disaster Recovery. The University of Chicago Press, Chicago

Atsumi, T. (2001) Borantyia no Chi (Wisdom of Volunteers). Osaka University Press, Osaka (in Japanese).

Atsumi, T. (2009) Acceptance in a Disaster Area: Process Technologies for Implementation Scientists. Journal of Natural Disaster Science. 30:97-103.

Atsumi, T., and Goltz, J.D. (2014) Fifteen Years of Disaster Volunteers in Japan: A Longitudinal Fieldwork Assessment of a Disaster Non-Profit Organization. International Journal of Mass Emergencies and Disasters. 32(1): 220-240. 
Atsumi, T., Seki, Y. and Yamaguchi, H. (in press) The Generative Power of Metaphor: Long-Term Action Research into the Recovery from Disaster of Survivors in a Small Village. Disasters. (Accepted 28-Sep-2017, Manuscript ID DISA-Mar-16-1951.R2)

Cabinet of Japan (2016) "Bosai 4.0" Mirai Kousou Project Yushikisha Teigen (The Proposal by the panel of experts for "Disaster Prevention 4.0" Future vision project) (in Japanese). http://www.bousai.go.jp/kaigirep/kenkyu/miraikousou/pdf/yushikisya_honbun.pdf

Cabinet Secretariat of Japan (2016) Kokudo Kyoujinka towa: Tsuyokute Shinayaka na Nippon he (National Resilience: for Strong and supple Japan) (in Japanese). http://www.cas.go.jp/jp/seisaku/kokudo_kyoujinka/pdf/kokudo_pamphlet.pdf

Cayley, D. (1992) Ivan Illich in Conversation. House of Anansi Press, Concord, Ontario.

Danowski, J. A. (1993) Network analysis of message content. IN Richards, W. D., and Barnett, G. A. (Eds.), Progress in Communication Sciences IV.197-221 Ablex, Norwood, New Jersey.

Emerson, R., Fretz, R., and Shaw, L. (1995) Writing Ethnographic Fieldnotes. University of Chicago Press, Chicago.

Engeström, Y. (1987). Learning by Expanding: An Activity Theoretical Approach to Developmental Research. Orienta-Konsultit Oy, Helsinki.

Higuchi, K. (2013) Co-occurrence Networks. https://sourceforge.net/p/khc/discussion/222396/thread/2da0ff02/

Higuchi, K. (2016) A Two-Step Approach to Quantitative Content Analysis: KH Coder Tutorial Using Anne of Green Gables (Part I). Ritsumeikan Social Sciences Review. 52(3): 77-91

Higuchi, K. (2017) A Two-Step Approach to Quantitative Content Analysis: KH Coder Tutorial Using Anne of Green Gables (Part II). Ritsumeikan Social Sciences Review. 53(1): 137-147.

Imamura, H., Sonoda, S., and Kaneko, I. (2010) Komyuniti no Chikara: "Enryo Gachi" na Sosharu Kyapitaru no Hakken (Power of Community: Discovery of "considerate" social capital). Keio University Press, Tokyo (in Japanese).

Iwahori, T., Yamori, K., Miyamoto, T., Shiroshita, H., and Iio, Y. (2017) Disaster Education Based on Legitimate Peripheral Participation Theory: A New Model of Disaster Science Communication. Journal of Natural Disaster Science, 38(1):1-15.

Jishin Itsumo Project (2007) Jishin Itsumo Note: Hanshin Aawaji Daishinsai no Hisaisha 167 Nin ni Kiita Kimochi no Bousai Manyuaru (Habitualy Note for Eathquakes: Disaster Pevention Manual of yourself Constructed by hearing from the 167 victims of the Great Hanshin-Awaji earthquake) Kiraku-sha, Tokyo (in Japanese).

Johnson V. A., Ronan K. R., Johnston, D. M., and Peace, R. (2016) Improving the Impact and Implementation of Disaster Education: Programs for Children Through Theory-Based Evaluation. Risk Analysis, 36(11):2120-2135.

Kaji A. H., Langford V., and Lewis R. J. (2008) Assessing Hospital Disaster Preparedness: a Comparison of an On-site Survey, Directly Observed Drill Performance, and Video Analysis of Teamwork. Annals of Emergency Medicine, 52(3):195-201.

Katada, T., and Kanai, M. (2016) The School Education to Improve the Disaster Response Capacity : A Case of "Kamaishi Miracle". Journal of disaster research, 11(5):845-856. 
Kawata, Y. 1997. Daikibo Jishin Saigai ni Yoru Jinteki Higai no Yosoku (Prediction of Loss of Human Lives Due to Catastrophic Earthquake Disaster). Natural Disaster Science, 16(1): 313 (in Japanese with English abstract).

Kusatsu City (2015) Kusatsu shi Jinkou Bijyon (Kusatsu City Population Vision). https://www.city.kusatsu.shiga.jp/shisei/seisaku/shikeikaku/sousei/kikaku320160328.files/bijy on.pdf

Lave, J. and Wenger, E. (1991) Situated learning: Legitimate peripheral participation. Cambridge University Press, Cambridge.

Lévi-Strauss, C. (1962) La Pensee Sauvage. Paris: Plon. (George Weidenfeld and Nicolson Ltd. (Trans.) (1966) The Savage Mind. Chicago: University of Chicago Press.)

Osgood, C.E. (1959) The Representational Model and Relevant Research Method. IN Pool, I. S. (Eds.), Trends in Content Analysis. University of Illinois Press, Urbana, Illinois.

Showstack, R. (2012) ShakeOut Drill Emphasizes Importance of Earthquake Preparedness, Education. Eos, 93(44): 439.

Simpson, D. M. (2002) Earthquake Drills and Simulations in Community- based Training and Preparedness Programmes. Disasters, 26(1): 55-69.

Sugiman, T. (2016) Introduction to Group Dynamics: Social Construction Approach to Organizational Development and Community Revitalization. Taos Institute Publications, Chagrin Falls, Ohio.

https://www.taosinstitute.net/Websites/taos/images/PublicationsWorldShare/2016_2_final_ver sion_Redacted.pdf

Sun, Y., Yamori, K., and Kondo, S. (2014). Single-person Drill for Tsunami Evacuation and Disaster Education. Journal of Integrated Disaster Risk Management, 4(1), doi: $10.5595 /$ idrim.2014.0080

Sun, Y., Yamori, K., Suzuki, S., Lee, F., Sugiyama, T., Chijiwa, S., Nishino, T., and Urabe, K. (2017) Sumaho Apuri de Tsunami Hinan no Sokushin Taisaku wo Kanngaeru (Can Smartphone Apps Motivate Tsunami Evacuation?). Journal of Information Processing, 58(1): 205-214. (in Japanese with English abstract)

Miyamoto, T. (1972) Chosachi Higai: Sareru Gawa no Samazama na Meiwaku (Scientific Harrassment: Various Annoyances in Accepting Side) IN Asahi kouza: Tanken to Bouken 7 (Asahi Lecture Series : Exploration and Adventure 7). The Asahi Shimbun Company, Tokyo (in Japanese).

Nagata, H. (2013) Toshi Seikatsusha no Tame no Bousai: Fudan no Sonae wo Dezain Suru. (Disaster Prevention for Urban Dwellers: Design for Regular Preparation). CEL, 103:8-11 (in Japanese). http://www.og-cel.jp/search/_icsFiles/afieldfile/2013/02/27/03.pdf

Vygotsky, L. S. (1978) Mind in society. Harvard University Press, Cambridge.

Watanabe, T. (1999) Chiiki Shakai Niokeru 5 Nenme no Kokoromi: Chiiki Bousai towa Iwanai Chiiki Bousai no Jissen to Sono Shuudannrikigakuteki Kousatsu (Trials in Communities Five Years after the Great Hanshin-awaji Earthquake: Group Dynamics of Preventing Disaster WITHOUT Saying Disaster Prevention). Japanese Journal of Experimental Social Psychology, 39:188-196 (in Japanese with English abstract) 